\title{
Pengembangan Media Booklet Materi Aksara Jawa dengan Penguatan Gemar Membaca Kelas IV SDN Srengat 1 Kabupaten Blitar
}

\author{
Aditya Anggi Pratama*, Suhel Madyono, Sutansi \\ Universitas Negeri Malang, Jl. Semarang No. 5 Malang, Jawa Timur, Indonesia \\ *Penulis korespondensi, Surel: adityaanggipratama@gmail.com
}

Paper received: 3-3-2021; revised: 24-3-2021; accepted: 28-3-2021

\begin{abstract}
The purpose of this research is to produce a product in the form of a media booklet for Javanese script material with a strengthening of reading fondness for class IV that is valid, practical, and interesting. his study uses the Borg and Gall research model. The results of the material expert validation were 95 percent (very valid), media expert 98 percent (very valid), users (teachers) 95 percent (very practical), and students 91 percent (very interesting). Based on the entire analysis of the booklet it can be concluded that the booklet is very suitable for use in learning Javanese script material.
\end{abstract}

Keywords: Javanese material booklet; the character like to read

\begin{abstract}
Abstrak
Tujuan penelitian ini adalah menghasilkan produk berupa media booklet materi aksara Jawa dengan penguatan gemar membaca untuk kelas IV yang valid, praktis, dan menarik. Penelitian ini menggunakan model penelitian Borg and Gall. Hasil validasi ahli materi 95 persen (sangat valid), ahli media 98 persen (sangat valid), pengguna (guru) 95 persen (sangat praktis), dan siswa 91 persen (sangat menarik). Berdasarkan seluruh hasil analisis booklet dapat disimpulkan bahwa booklet sangat layak digunakan dalam pembelajaran materi aksara Jawa.
\end{abstract}

Kata kunci: booklet materi aksara jawa; karakter gemar membaca

\section{Pendahuluan}

Aksara Jawa masih dianggap sebagai salah satu momok yang menakutkan bagi pembelajaran, utamanya generasi muda yang mempelajari bahasa Jawa. Bayangan sulitnya menghafal bentuk-bentuk huruf yang rumit juga banyaknya huruf yang harus dihafal. Sedangkan, siswa juga membutuhkan cara yang cepat dan mudah dalam menulis menggunakan aksara Jawa (Sutarsih, 2015). Pembelajaran bahasa Jawa secara paktis di kelas berisi kegiatan-kegiatan yang mengarahkan siswa kepada pemerolehan keterampilan berbahasa Jawa (Maruti, 2016). Oleh karena itu, keterampilan bahasa Jawa hingga saat ini masih perlu di budayakan. Bahasa Jawa merupakan salah satu bahasa daerah yang sangat perlu dilestarikan agar tidak hilang keberadaannya, salah satu cara melestarikan bahasa Jawa adalah dengan membudayakan membaca dan menulis aksara Jawa.

Penelitian pengembangan media booklet ini dilakukan untuk siswa kelas IV SDN Srengat 1 Kabupaten Blitar karena kurangnya Media bahasa Jawa khusunya mengenai aksara Jawa di SDN Srengat 1 Kabupaten Blitar belum optimal. Media pembelajaran sebatas guru menuliskan aksara Jawa di papan tulis sebagai media belajar. Pada tanggal 16 Desember 2019 dilakukan wawancara dengan guru kelas IV dan siswa untuk mengetahui ketersediaan media pembelajaran bahasa Jawa dan proses pembelajaran. Media pembelajaran yang digunakan untuk memfasilitasi siswa belajar materi aksara Jawa adalah buku Tantri Basa Adhedhasar. 
Saat wawancara pada siswa diperoleh pembelajaran masih dominan menerima pembelajaran melalui metode ceramah. Siswa hanya menerima informasi dari penjelasan guru dan menyalin dari papan tulis ke buku tulis siswa. Ketika pembelajaran bahasa Jawa mengenai aksara Jawa pembelajaran berjalan baik, namun selanjutnya terlihat indikasi kurangnya konsentrasi belajar siswa. Beberapa siswa mulai mengalihkan perhatiannya pada hal lain, seperti mengobrol dengan teman, mengantuk, mencoret buku, melamun, dan bermain sendiri. Pembelajaran bahasa Jawa yang baik harus dapat mengarahkan seseorang dapat berkomunikasi dengan bahasa Jawa yang santun dan berbudi pekerti luhur sesuai dengan budaya Jawa (Kurniati, 2015).

Berdasarkan permasalahan tersebut, peneliti memberikan solusi yaitu dengan mengembangkan media guna mempermudah segala aktivitas. Pada dunia pendidikan media berkembang cukup pesat. Media pembelajaran merupakan segala bentuk peralatan fisik dan didesain untuk menyampaikan informasi dan membangun interaksi. Peralatan fisik yang dimaksud meliputi benda asli, bahan cetak, visual, audio, audio visual, multimedai, dan web. Peralatan tersebut harus bisa digunakan menyampaikan informasi yang memiliki isi pesan pembelajaran agar siswa dapat mengkosntruksi pengetahuan dengan efektif serta efisien (Yaumi, 2018). Media yang dibuat berupa booklet materi aksara Jawa dengan penguatan gemar membaca untuk kelas IV yang diidentifikasi dari Permendiknas Nomor 22 Tahun 2006 dengan KD 4.6. Booklet memiliki beberapa kelebihan yaitu merupakan media cetak yang praktis, booklet memicu kemandirian siswa, bersifat permanen, mudah disimpan, diambil kembali dan dibaca sesuai dengan kemampuan pembaca (Baragay, dkk 2016). Kelebihan booklet dalam penelitian ini yaitu pada kelebihan booklet dalam pengembangan ini belum ada yang mengembangkan muatan bahasa Jawa terutama materi aksara Jawa, dilengkapi gambargambar ilustrasi yang sesuai dengan materi yang disajikan.

Dalam penelitian ini, booklet dikembangkan untuk membangun suatu karakter. Salah satu nilai pendidikan karakter dalam Permendikbud No. 20 Tahun 2018 adalah gemar membaca. Gemar membaca akan mampu mengembangkan pola berpikir kreatif dalam diri mereka. Budaya gemar membaca perlu diterapkan secara menyeluruh karena perkembangan tekhnologi yang semakin maju membuat budaya minat membaca semakin banyak mengalami penurunan. Pada proses pembelajaran di sekolah guru dapat meningkatkan semangat gemar membaca melalui hadirnya beragam bacaan yang menarik siswa. Sumber bacaan tersebut dapat dikemas dengan pengembangan media pembelajaran cetak yaitu booklet sebagai salah satu solusinya.

\section{Metode}

Metode penelitian ini menggunakan penelitian pengembangan dengan model Borg and Gall menurut modifikasi Sugiyono (2016) yang terdiri dari sepuluh langkah yaitu potensi dan masalah, pengumpulan data, desain produk, validasi desain, perbaikan desain, uji coba produk, revisi produk, uji coba pemakaian, revisi produk final, produksi masal. Subjek penelitian pengembangan pocket book adalah siswa kelas IV SDN Srengat 1 Kabupaten Blitar. Instrumen yang digunakan berupa angket terbuka dan tertutup yang ditujukan kepada validator ahli materi, ahli bahan ajar, pengguna (guru), dan siswa berupa angket respon.

Pengumpulan data penelitian melalui wawancara dan angket. Wawancara digunakan untuk menganalisis kebutuhan guru. Angket yang digunakan ada dua yaitu, 
angket pertama untuk validator. Angket kedua untuk siswa untuk mengetahui kemenarikan terhadap penggunaan booklet. Jenis data berupa data kuantitatif dan kualitatif. Data kuantitatif diperoleh dari uji kevalidan, implementasi skala kecil, implementasi skala besar melalui angket yang diberikan kepada validator ahli materi, ahli bahan ajar, pengguna (guru), dan siswa. Angket tersebut digunakan untuk mengetahui persentase kevalidan, kepraktisan, dan kemenarikan booklet. sedangkan data kualitatif diperoleh dari saran dan masukan dari ahli materi, ahli bahan ajar, pengguna (guru), dan siswa yang digunakan untuk menyempurnakan booklet. Data kuantitatif dianalisis dengan teknik analisis kuantitatif. Setiap indikator diberikan skor 1-4. Sedangkan data dari siswa yang diperoleh dari implementasi skala kecil dan implementasi skala besar dianalisis menggunakan skala Guttman.

Perolehan skor dari validator ahli materi, ahli bahan ajar, dan pengguna (guru) diubah menjadi persentase dengan rumus dari Akbar (dalam Arif, dkk, 2015).

$V a h=\frac{T s e}{T s h} \times 100 \%$

Keterangan:

Vah = validasi ahli

Tse = total skor empirik yang diperoleh

Tsh $=$ total skor empirik maksimal

Data yang diperoleh dari angket siswa dianalisis menggunakan skala Guttman. Hasil angket dianalisis menggunakan rumus dari Arikunto (dalam Arif, dkk, 2015).

$P=\frac{\sum x}{N} \times 100 \%$

Keterangan:

$\mathrm{P} \quad=$ persentase skor

$\sum \mathrm{x} \quad=$ jumlah skor

$\mathrm{N} \quad=$ jumlah skor maksimal

Tabel 1. Kategori Hasil Validasi Ahli Materi, Ahli Media, Pengguna, dan Siswa

\begin{tabular}{lll}
\hline Tingkat Pencapaian (\%) & Kategori & Keputusan Uji \\
\hline $86,00-100,00$ & Sangat valid & Sangat baik untuk digunakan \\
$71,00-85,00$ & Valid & Boleh digunakan dengan revisi kecil \\
$50,00-70,00$ & Cukup valid & Boleh digunakan dengan revisi besar \\
$41,00-50,00$ & Kurang valid & Tidak boleh digunakan \\
$25,00-40,00$ & Tidak valid & Tidak boleh digunakan \\
\hline
\end{tabular}

Sumber: Akbar (2013:78)

Berdasarkan tabel 1 hasil validasi untuk pengembangan media booklet penguatan gemar membaca dapat dimanfaatkan apabila presentase kevalidan dapat mencapai diatas 70\%. Apabila presentase kevalidan belum mencapai 70\% maka baru dilakukan revisi terhadap produk berdasarkan saran dari Validasi ahli, pengguna, dan angket siswa. 


\section{Hasil dan Pembahasan}

\subsection{Hasil}

Beberapa tampilan produk booklet yang telah dibuat adalah sebagai berikut.
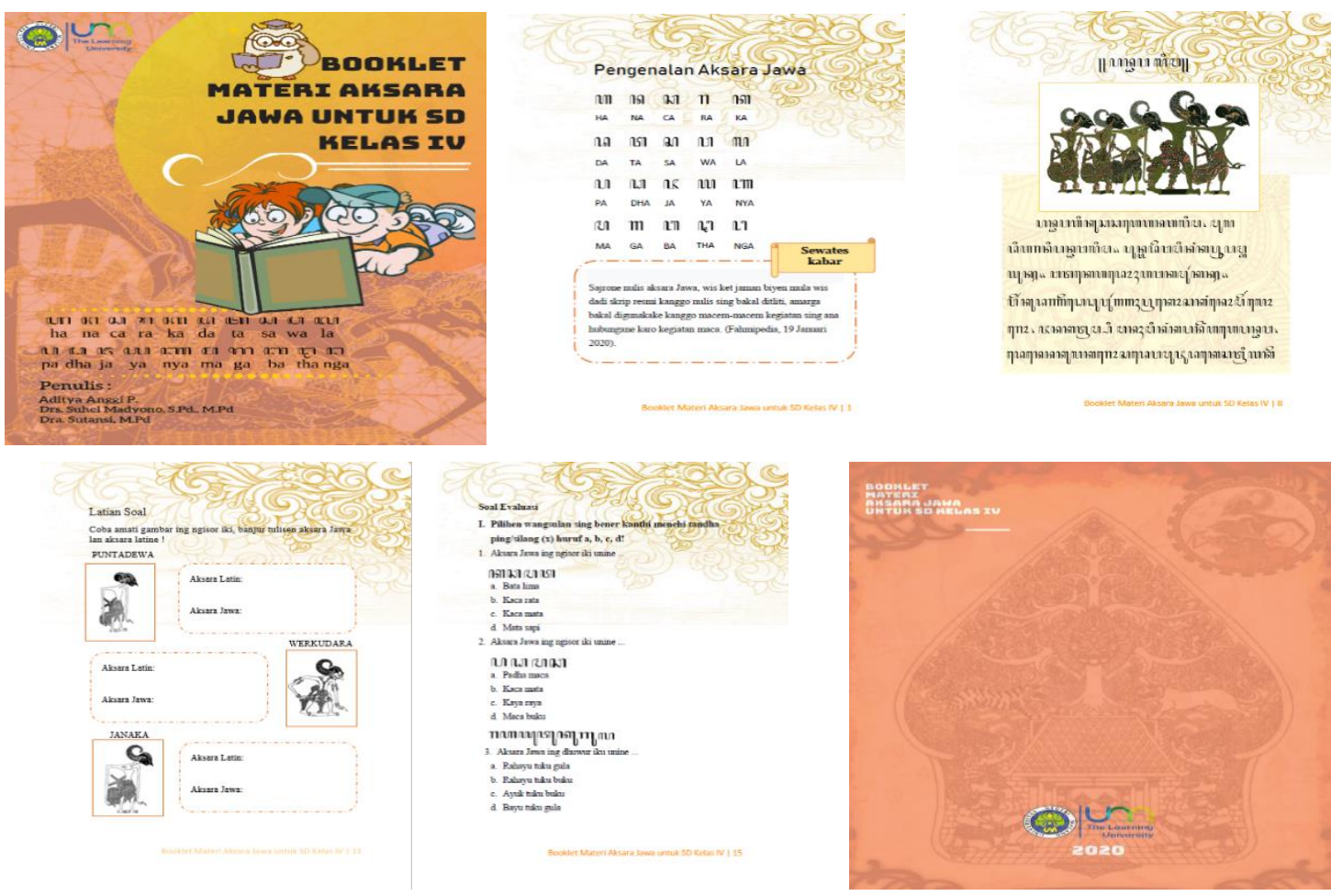

Gambar 1. Tampilan Produk Booklet Materi Aksara Jawa

Booklet materi aksara Jawa divalidasi oleh ahli materi, ahli media, dan pengguna (guru). Hasil validasi diperoleh dari penilaian validator. Validasi ahli materi dilakukan satu kali. Hasil validasi ahli materi disajikan pada tabel 2.

Tabel 2. Hasil Validasi Ahli Materi

\begin{tabular}{lll}
\hline No & Aspek & Indikator Penilaian \\
\hline 1. & Penyajian booklet & Kelengkapan isi booklet \\
2. & Materi & Kesesuaian KD, tujuan, dan materi pembelajaran \\
& & Kemutakhiran materi \\
& & Penguatan karakter gemar membaca \\
3. & Bahasa & Kesesuaian dengan kaidah bahasa \\
& & Komunikatif \\
& & Dialogis dan Interaktif \\
& Kesesuaian dengan perkembangan siswa kelas IV SD \\
\hline & Total Nilai & 96 \\
\hline & Nilai Maksimal & 90 \\
\hline & Persentase Hasil Nilai & $95 \%$
\end{tabular}

Data pada tabel 2 dianalisis dengan menggunakan rumus Akbar (2013). Hasil dari perhitungan validasi mencapai hasil sebesar 95\%. Sehingga dapat dinyatakan bahwa booklet sangat valid dan dapat digunakan tanpa revisi. 
Validasi Media dilakukan satu kali. Hasil validasi disajikan pada tabel 3.

Tabel 3. Hasil Validasi Ahli Media

\begin{tabular}{lll}
\hline No & Indikator Penilaian & Butir Penilaian \\
\hline 1. & Penyajian booklet & Kelengkapan isi booklet \\
2. & Tampilan booklet & Ukuran booklet \\
& & Desain sampul booklet \\
& & Desain isi booklet \\
3. & Bahasa & Kesesuaian dengan kaidah bahasa \\
& & Ketepatan struktur kalimat \\
& & Terdapat kata-kata yang sulit untuk dipahami \\
\hline & Total Nilai & 74 \\
\hline & Nilai Maksimal & 75 \\
\hline & Persentase Hasil Nilai & $98 \%$ \\
\hline
\end{tabular}

Data pada tabel 3 dianalisis dengan menggunakan rumus Akbar (2013: 78). Hasil dari perhitungan validasi pocket book mencapai hasil sebesar $98 \%$. Sehingga dapat dinyatakan bahwa booklet sangat valid dan dapat digunakan tanpa revisi.

Validasi pengguna (guru) dilakukan satu kali. Hasil validasi disajikan pada tabel 4.

Tabel 4. Hasil Validasi Pengguna (Guru)

\begin{tabular}{lll}
\hline No & Indikator Penilaian & Butir Penilaian \\
\hline 1. & Penyajian booklet & Kelengkapan isi booklet \\
2. & Materi & Kesesuaian KD, tujuan, dan materi pembelajaran \\
& & Kemutakhiran materi \\
& & Penguatan karakter gemar membaca \\
3. & Tampilan booklet & Ukuran booklet \\
& & Desain sampul booklet \\
& & Desain isi booklet \\
4. & Bahasa & Kesesuaian dengan kaidah bahasa \\
& & Ketepatan struktur kalimat \\
& & Terdapat kata yang sulit untuk dipahami \\
& & Kesesuaian dengan perkembangan siswa SD kelas IV \\
\hline & Total Nilai & 124 \\
\hline & Nilai Maksimal & 130 \\
\hline & Persentase Hasil Nilai & $95 \%$ \\
\hline
\end{tabular}

Data pada tabel 4 dianalisis dengan menggunakan rumus Akbar (2013: 78). Hasil dari perhitungan validasi mencapai hasil sebesar 95\%. Sehingga dapat dinyatakan bahwa booklet sangat praktis dan dapat digunakan tanpa revisi.

Setelah booklet divalidasi dan direvisi. Adapun beberapa masukan dari validator disajikan pada tabel 5 . 
Tabel 5. Saran dan Masukan Terhadap boklet

\begin{tabular}{ll} 
No. & Saran dan Masukan \\
\hline 1. & Gambar di sampul diganti karena masih ada watermark. \\
2. & Materi tentang cerita wayang kurawa diganti karena memiliki amanat kurang baik. \\
3. & Materi soal tentang penamaan tokoh wayang dimunculkan . \\
4. & Pencetakan harus sesuai dengan A5. \\
5. & Penghilangan garis putih ketika pencetakan booklet.
\end{tabular}

Setelah booklet divalidasi dan direvisi selanjutnya dilakukan uji coba. Uji coba terdiri dari uji skala kecil dan uji skala besar. Uji coba produk dilakukan dengan skala kecil yaitu oleh 8 siswa kelas IV yang ada di lingkungan tempat tinggal peneliti dan uji coba pemakaian dengan skala besar dilaksanakan oleh 11 siswa klas IV yang ada di lingkungan tempat tinggal peneliti. Hasil uji coba produk skala kecil disajikan pada tabel 6 sebagai berikut.

Tabel 6. Angket Respon Siswa

\begin{tabular}{lll}
\hline No & Indikator Penilaian & Butir Penilaian \\
\hline 1. & Tampilan booklet & Gambar sampul booklet \\
& & Gambar dalam isi booklet \\
& & Booklet berwarna dan menarik \\
2. & Kebahasaan & Huruf yang digunakan mudah dibaca \\
& & Ukuran huruf sesuai \\
& & Kesesuaian dengan kaidah bahasa \\
3. & Peneguatan Karakter & Dapat mengerjakan soal \\
& Gemara membaca & Menyiapkan alat tulis \\
& & Tidak meminjam alat tulis \\
& & Meningkatkan gemar membaca \\
\hline & Total Nilai & 70 \\
\hline & Nilai Maksimal & 80 \\
\hline & Presentase Hasil Nilai &
\end{tabular}

Data pada tabel 6 dianalisis dengan menggunakan skala Guttman. Hasil angket dianalisis menggunakan rumus dari Arikunto (dalam Arif, dkk, 2015). Hasil dari perhitungan kemenarikan mencapai hasil $87 \%$ sehingga dapat dinyatakan bahwa booklet sangat menarik dan dapat digunakan tanpa revisi. Pelaksanaan uji coba produk skala besar dilaksanakan kepada 11 siswa lingkungan sekitar tempat tinggal saudara dari peneliti. Hasil uji coba produk skala besar disajikan pada tabel 7 sebagai berikut. 
Tabel 7. Angket Respon Siswa

\begin{tabular}{lll}
\hline No & Indikator Penilaian & Butir Penilaian \\
\hline 1. & Tampilan booklet & Gambar sampul booklet \\
& & Gambar dalam isi booklet \\
& & booklet berwarna dan menarik \\
2. & Kebahasaan & Huruf yang digunakan mudah dibaca \\
& & Kkuran huruf sesuai \\
& & Kesesuaian dengan kaidah bahasa \\
3. & Peneguatan Karakter & Menyiapkan alat tulis \\
& Gemara membaca & Tidak meminjam alat tulis \\
& & Meningkatkan gemar membaca \\
\hline & Total Nilai & 100 \\
\hline & Nilai Maksimal & 110 \\
\hline & Presentase Hasil Nilai & $91 \%$ \\
\hline
\end{tabular}

Data pada tabel 7 dianalisis menggunakan skala Guttman. Hasil angket dianalisis menggunakan rumus dari Arikunto (dalam Arif, dkk, 2015). Hasil dari perhitungan kemandirian mencapai hasil $91 \%$ sehingga dapat dinyatakan bahwa booklet sangat menarik dan dapat digunakan tanpa revisi.

\subsection{Pembahasan}

Kevalidan booklet berdasarkan penilaian ahli materi dan ahli media. Ahli materi dan Media menilai penyajian booklet, materi, dan bahasa. Keberadaan media pembelajaran dalam dunia pendidikan tentunya memiliki beberapa fungsi penting. Berdasarkan penjelasan dari Suherman (2009) diketahui fungsi dari media pembelajaran meliputi; (a) perantara untuk memperjelas penyajian pesan dan informasi; (b) adanya media pembelajaran mampu meningkatkan perhatian siswa, sehingga memungkinkan siswa untuk belajar sendiri; (c) keberadaan media mampu mengatasi keterbatasan indera, ruang, waktu; (d) Media pembelajaran dapat meningkatkan proses dan hasil pembelajaran siswa. Hasil dari validasi ahli materi dan ahli media adalah 95\% dan 98\% dengan kategori sangat valid dan dapat digunakan tanpa revisi. Hasil validasi sesuai dengan tujuan pengembangan booklet yaitu valid menurut ahli materi dan ahli bahan ajar.

Kepraktisan booklet berdasarkan penilaian pengguna (guru). Pengguna menilai empat aspek yaitu penyajian booklet, materi, tampilan booklet, dan bahasa. (Khoirunnisa, 2018) Dalam proses pembelajaran booklet yang dipergunakan untuk sumber belajar bermanfaat menarik minat dan perhatian siswa, karena memiliki bentuk sangat sederhana juga disertai dengan banyaknya warna dan ilustrasi. Selain itu, booklet bisa dijadikan media pembelajaran mandiri oleh siswa karena memiliki fungsi praktis yaitu dapat dibaca dimana saja serta kapan saja menjadikan pemahaman siswa akan materi meningkat. Hasil kepraktisan booklet $95 \%$ dengan kategori sangat praktis dan dapat digunakan tanpa revisi. Hasil validasi sesuai dengan tujuan pengembangan booklet yaitu praktis menurut pengguna.

Kemenarikan booklet berdasarkan penilaian siswa melalui uji skala kecil dan uji skala besar. Hasil uji coba skala kecil adalah $87 \%$ sehingga dapat dikategorikan sangat menarik dan dapat digunakan tanpa revisi. Respon siswa setelah menggunakan booklet sangat positif. Booklet sangat menarik, menyenangkan, mudah dipahami, dan dapat memotivasi untuk 
belajar. Hasil kemenarikan implementasi skala besar adalah 91\% sehingga dapat dikategorikan sangat menarik dan dapat digunakan tanpa revisi. Berdasarkan hasil skala besar didapatkan beberapa temuan yaitu: (1) siswa sangat suka belajar menggunakan booklet, (2) siswa suka dengan gambar-gambar, tampilan, dan penataan materi yang ada di dalam booklet karena menarik, (3) siswa menjadi lebih mudah dalam memahami materi karena karena isinya ringkas dan dapat dihafalkan. Hal tersebut sesuai dengan pendapat Baragay, dkk (2016) booklet memiliki kelebihan antara lain: (1) merupakan media cetak yang praktis, mudah dibawa kapanpun dan dapat dibaca dimana saja, serta tidak memerlukan listik, (2) booklet memicu kemandirian peserta didik dan memuat peserta didik dapat belajar sesuai dengan kemampuannya masing-masing, (3) booklet mengurangi kegiatan mencatat, (4) pesan pada booklet bersifat permanen, mudah disimpan, diambil kembali dan dibaca sesuai dengan kemampuan pembaca. Hasil dari uji skala kecil dan uji skala besar sesuai dengan tujuan pengembangan booklet yaitu menarik menurut siswa.

Produk booklet materi aksara Jawa dengan penguatan gemar membaca kelas IV telah di validasi tiga ahli yaitu ahli materi, media, dan yang terakhir pengguna (guru). Tahapan lanjutan dilakukan uji skala kecil. Uji coba skala kecil dilakukan di rumah pengembang produk booklet materi aksara Jawa dengan penguatan gemar membaca kelas IV yaitu rumah peneliti, Kecamatan Wonosalam, Kabupaten Jombang pada tanggal 16 April 2020. Uji coba skala kecil yang seharusnya bertempat di SD dilakukan di rumah peneliti dengan mencari siswa kelas IV SD dari lingkungan sekitar, semua itu dilakukan karena adanya pandemi virus Covid 19. Siswa kelas IV SD dari lingkungan sekitar tempat tinggal pengembang dapat terkumpul dengan jumlah 8 anak. Kegiatan uji coba skala kecil dimulai pada pengenalan produk serta pembagian booklet materi aksara Jawa dengan penguatan gemar membaca kelas IV kepada delapan anak, kemudian penggunaan produk booklet, dan yang terakhir pengisian angket.

Uji coba skala kecil memiliki tujuan yaitu untuk mengetahui kekurangan produk, jika ada perlu adanya revisi ringan sebelum dilanjut ke uji coba pada skala besar. Hasil angket uji skala kecil dan besar memiliki jumlah 87\%. Jumlah tersebut menunjukkan bahwa produk booklet materi aksara Jawa dengan penguatan gemar membaca kelas IV layak untuk ke tahap selanjutnya yakni uji skala besar. Sedikit saran dan masukan sesudah uji skala kecil yaitu pada latihan soal mengenai gambar wayang Pandhawa lima sebaiknya dibawah gambar tokoh, nama wayang tersebut dituliskan.

Uji skala besar dilaksanakan pada tanggal tanggal 21 April 2020, Adanya pandemi virus Covid 19 yang belum menunjukkan tanda-tanda mereda maka pelaksanaan uji coba skala besar dilaksanakan di rumah saudara dari peneliti, Kecamatan Kepung, Kabupaten Kediri. Siswa kelas IV SD dari lingkungan sekitar tempat tinggal saudara dari pengembang dapat terkumpul dengan jumlah 11 anak. Secara teknisuji skala kecil dan besar tidak jauh berbeda. Proses ini meliputi, pengenalan booklet materi aksara Jawa dengan penguatan gemar membaca kelas IV, penggunaan produk booklet, dan yang terakhir pengisian angket. Hasil angket menunjukan bahwa booklet materi aksara Jawa dengan penguatan gemar membaca kelas IV layak digunakan dengan memperoleh jumlah 91\%. Tidak ada saran dan masukan pada uji skala besar.

Hasil validasi oleh ahli materi pada produk booklet materi aksara Jawa dengan penguatan gemar membaca kelas IV sangat valid, praktis, dan layak untuk digunakan. Perihal tersebut ditunjukkan dengan perolehan validasi materi sebesar 95\%, hasil tersebut 
didapatkan dari total skr sebesar 86 dibagi dengan skor maksimal yaitu 90 dikali $100 \%$. Validasi oleh ahli media menunjukkan hasil sebesar $98 \%$, hasil tersebut didapat dari total skr sebesar 74 dibagi dengn skor maksimal 75 dikali 100\%. Validasi pengguna menunjukkan hasil sebesar 95\%, hasil tersebut didapat dari total skr sebesar 124 dibagi dengan skor maksiml 130 dikali 100\%. Hasil angket respon siswa menunjukkan hasil 91\% hasil tersebut diperoleh dari total skr 100 dibagi dengan skr maksimal 110 dikali 100\%.

\section{Simpulan}

Berdasarkan tujuan penelitian dapat disimpulkan bahwa menurut ahli materi produk booklet materi aksara Jawa sangat valid, kelayakan isi booklet materi aksara Jawa memperoleh persentase sebesar 95\%. Menurut ahli media produk booklet sangat valid, tampilan desain booklet materi aksara Jawa memperoleh persentase sebesar 98\%. Menurut guru sebagai pengguna produk booklet materi aksara Jawa sangat valid, memperoleh persentase $95 \%$. Menurut data hasil uji coba skala kecil terhadap 8 siswa kelas IV SD lingkungan sekitar produk booklet materi aksara Jawa sangat valid, memperoleh persentase $87 \%$. Sedangkan menurut data hasil uji coba skala besar terhadap 11 siswa kelas IV SD produk booklet materi aksara Jawa sangat valid, memperoleh persentase 91\%.

Produk booklet materi aksara Jawa sebaiknya dapat dikembangkan lebih luas lagi. Jadi tidak hanya berbentuk cetak yaitu booklet, pengembang berharap pengembang selanjutnya mampu berinovasi karena tekhnologi semakin berkembang untuk itu materi aksara Jawa juga dapat dikembangkan menjadi berbasis digital seperti video pembelajaran interaktif, powerpoint interaktif agar ketertarikan siswa tentang media tersebut menjadi lebih meningkat.

\section{Daftar Rujukan}

Akbar, S. (2013). Instrumen Perangkat Pembelajaran. Bandung: PT Karya Rosadkarya.

Baragay, F. E. \& Mintjelungan, C. N. (2016). Perbedaan Efektifitas DHE dengan Media Booklet dan Media Filp Chart terhadap Peningkatan Pengetahuan Kesehatan Gigi dan Mulut Siswa SDN 126 Manado. Jurnal eGiGi, 4(2), 76-82.

Kurniati, E. (2015). Implementasi Pembelajaran Bahasa Jawa SD yang Integratif Komunikatif Berbasis Folklore Lisan sebagai Wujud Konservasi Budaya. Jurnal Penelitian pendidikan. 32 (2), 1-12.

Maruti, S. E. (2016). Pembelajaran Bahasa Jawa di Sekolah Dasar. Magetan: CV. AE. Media Grafika.

Permendiknas No. 22. (2006). Permendikbud No. 22 Tahun 2006 tentang Kompetensi Dasar. Jakarta. Mendiknas.

Permendikbud No. 20. (2018). Permendikbud No. 20 Tahun 2018 tentang Penguatan Pendidikan Karakter. Jakarta. Mendikbud.

Sugiyono. (2016). Metode Penelitian Pendidikan (Pendekatan Kuantitatif, Kualitatif, dan R\&D). Bandung: Alfabeta.

Suherman, Y. (2009). Pengembangan Media Pembelajaran Bagi ABK. Makalah disampaikan pada Diklat Profesi Guru PLB Wilayah X Jawa Barat Bumi Makmur.

Sutarsih. (2015). Pembelajaran Menulis Aksara Jawa Anak Kelas III Sekolah Dasar. Jurnal Aksara, 27 (1).

Yaumi, M. (2018). Media dan Teknologi Pembelajaran. Jakarta: Prenadamedia Group. 